$12-2018$

\title{
The Duty to Prevent Genocide under International Law: Naming and Shaming as a Measure of Prevention
}

Björn Schiffbauer

University of Cologne, Germany

Follow this and additional works at: https://digitalcommons.usf.edu/gsp

\section{Recommended Citation}

Schiffbauer, Björn (2018) "The Duty to Prevent Genocide under International Law: Naming and Shaming as a Measure of Prevention," Genocide Studies and Prevention: An International Journal: Vol. 12: Iss. 3:

83-94.

DOI:

https://doi.org/10.5038/1911-9933.12.3.1569

Available at: https://digitalcommons.usf.edu/gsp/vol12/iss3/11

This Articles is brought to you for free and open access by the Open Access Journals at Digital Commons @ University of South Florida. It has been accepted for inclusion in Genocide Studies and Prevention: An International Journal by an authorized editor of Digital Commons @ University of South Florida. For more information, please contact digitalcommons@usf.edu. 
The Duty to Prevent Genocide under International Law: Naming and Shaming as a Measure of Prevention

\section{Acknowledgements}

This article is based on a contribution to the thirteenth meeting of the International Association of Genocide Scholars at the University of Queensland in Brisbane from July 9 to 13, 2017. 


\title{
The Duty to Prevent Genocide under International Law: Naming and Shaming as a Measure of Prevention
}

\author{
Björn Schiffbauer \\ University of Cologne \\ Cologne, Germany
}

\begin{abstract}
Introduction
"Genocide is not just an international crime, it is the international crime; to fight it is not an obligation, but [...] the obligation." ${ }^{1}$ This emphatic declaration by Christian Tams, Lars Berster and Björn Schiffbauer is not only a commitment to the unconditional fight against genocide but also and foremost reflects the cornerstone of the 1948 United Nations Convention for the Prevention and Punishment of the Crime of Genocide ${ }^{2}$ (UNCG). The quotation clearly points out what the duty to prevent genocide is all about in international law: It is not only part of the unalienable jus cogens ${ }^{3}$ -it is even among the highest of all unconditional obligations under international law because it affects the most fundamental conditions of the very existence of the international community. ${ }^{4}$ No State, no organization, not any reasonable person would deny that genocide is one of the most hideous international crimes, in allusion to Raphael Lemkin often and still rated the "crime of crimes". ${ }^{5}$ Accordingly, it is a fundamental condition of both international law and the very existence of mankind that any preparation or any act of aiding, abetting or committing genocide must be averted as early as possible. The UNCG (concluded on December 9, 1948, entered into force on January 12, 1951), for the first time, provided in its Article II a legal definition of genocide. ${ }^{6}$ From then, this definition of genocide has not remained without objection as to interpretative details; it also has been polished by further State practice on prosecuting genocide in domestic as well as international law. ${ }^{7}$ However, the core elements of what constitutes genocide have never been remarkably disputed. ${ }^{8}$ This is illustrated in the more recent international practice on treaty-making: The wording of Article 6 of the Rome Statute of the International Criminal Court ${ }^{9}$ (concluded on July 17, 1998, entered into force on July 1, 2002), which defines genocide for the purposes of that court, simply recites the UNCG. The general understanding of what constitutes genocide in legal terms has remained the same since 1948: the destruction of (at least) a national, ethnical, racial or religious group of human beings, which must be prevented and punished-without exception. Article I UNCG has carved this imperative to mankind in stone:
\end{abstract}

The Contracting Parties Confirm that genocide, whether committed in time of peace or in time of war, is a crime under international law which they undertake to prevent and punish.

${ }^{1}$ Christian Tams, et al., eds., "Introduction," in Convention on the Prevention and Punishment of the Crime of Genocide: A Commentary (Munich, Oxford, Baden-Baden: C.H. Beck, Hart, Nomos, 2014), para. 4.

${ }^{2}$ United Nations, General Assembly Resolution 260, Convention on the Prevention and Punishment of the Crime of Genocide, December 9, 1948 (UN Doc. A/RES/260(III)).

${ }^{3}$ The International Law Commission is still working on "Peremptory norms of general international law (Jus cogens)," but there has never been a doubt that the prohibition of genocide is part those norms: e.g. Dire Tladi, Second report on jus cogens, United Nations General Assembly, Sixty-ninth session, March 16, 2017. UN Doc. A/CN.4/707, paras. 44, 57, 85.

${ }^{4}$ See on the concepts of "jus cogens" and "international community" in general William E. Conklin, "The Peremptory Norms of the International Community," European Journal of International Law 23, no. 3 (2012), 837, particularly on genocide as one of the highest crimes in and against an international community 856.

${ }^{5}$ Reaching back to Raphael Lemkin, "Genocide as a Crime under International Law," United Nations Bulletin vol. IV, January 15, 1948, 70; relevant case-law starting with Prosecutor v. Kambanda, International Criminal Tribunal for Rwanda, Case No. 93-27-S, September 4, 1998, para.16, followed by numerous other decisions; see further William A. Schabas, Genocide in International Law, 2nd ed. (Cambridge: Cambridge University Press, 2010), 10.

${ }^{6}$ See for further details the analysis by Lars Berster, "Article II," in Convention on the Prevention and Punishment of the Crime of Genocide: A Commentary, ed. Christian Tams, et al. (Munich, Oxford, Baden-Baden: C.H. Beck, Hart, Nomos, 2014).

${ }^{7}$ See eg. Table of Cases in Convention on the Prevention and Punishment of the Crime of Genocide: A Commentary, ed. Christian Tams et al. (Munich, Oxford, Baden-Baden: C.H. Beck, Hart, Nomos, 2014), XXII.

${ }^{8}$ I.e. the annihilation of a whole group; a group's right to exist is the most important protected value in terms of genocide, see further Berster, Article II, para. 2.

${ }^{9}$ United Nations General Assembly, Rome Statute of the International Criminal Court, July 17, 1998, United Nations Treaty Series, vol. 2187, 3.

Björn Schiffbauer. "The Duty to Prevent Genocide under International Law: Naming and Shaming as a Measure of Prevention" Genocide Studies and Prevention 12, 3 (2018): 83-94. 02018 Genocide Studies and Prevention.

https://doi.org/10.5038/1911-9933.12.3.1569 
Although it took some time until the legal status of the UNCG's provisions became as solid as the text of Article I never hesitated to imply, at least the State practice from the 1990s until now has proven that the prevention of genocide is far more than a mere political agenda. ${ }^{10}$ Today the vast majority of States in the world has enacted criminal legislation against genocide, which (some more, some less) meets the UNCG's requirements. ${ }^{11}$ The international law duty to hold génocidaires criminally responsible seems to be widely implemented.

\section{The Duty to Prevent Genocide: A Legal Approach}

However, in contrast to prosecuting and punishing committed acts of genocide, the UNCG is silent as to means of preventing future acts. Although Article VIII UNCG clarifies that State parties "may call upon the competent organs of the United Nations" to take actions of genocide prevention, the wording "may" easily discloses that those referrals are optional in a political sense, but not legally binding upon Member States pursuant to Article VIII. ${ }^{12}$ In the subsequent practice of treaty application, Article VIII has indeed contributed to some institutional and political progress within the United Nations, ${ }^{13}$ but it has not proven to enrich the content of the peremptory state obligation to prevent genocide. ${ }^{14} \mathrm{After}$ all, the duty to prevent genocide in terms of international law is referred to only in Article I UNCG, as cited above. Today, it is generally recognized that Article I entails a legal duty to prevent genocide and is not only a programmatic statement. ${ }^{15}$ At the same time, States still seem to be unaware of even a minimum legal content of the duty to prevent enshrined in Article I UNCG. Therefore, a thorough legal interpretation of Article I UNCG is essential to ascertain how States can or even must fulfill their common duty to prevent genocide in order to comply with this important part of the international jus cogens.

\section{The Legal Tools: The Rules of Article 31 VCLT}

The interpretation of international treaties follows well-established rules, i.e. particularly the 1969 Vienna Convention on the Law of Treaties ${ }^{16}$ (VCLT) and corresponding (partly pre-existing) customary international law. Thus, the rules of the $\mathrm{VCLT}^{17}$ provide the legal tools to access the content of the duty to prevent genocide enshrined in Article I UNCG. The fundamental customary international law rule on treaty interpretation, ${ }^{18}$ reflected in Article 31 para. 1 , VCLT, demands that

\footnotetext{
${ }^{10}$ At the latest by involving the ICJ in genocide cases - which lead to the first genocide judgment, Bosnia and Herzegovina $v$. Yugoslavia, Application of the Convention on the Prevention and Punishment of the Crime of Genocide, Preliminary Objections, International Court of Justice, July 11, 1996 - the legal relevance of the crime of genocide and its prevention cannot be denied; see on the implementation of the UNCG further Tams, et al., "Introduction," foremost paras. 56.

${ }^{11}$ Listed in Annex 5 to Convention on the Prevention and Punishment of the Crime of Genocide: A Commentary, ed. Christian Tams et al. (Munich, Oxford, Baden-Baden: C.H. Beck, Hart, Nomos, 2014).

${ }^{12}$ Björn Schiffbauer, "Article VIII" in Convention on the Prevention and Punishment of the Crime of Genocide: A Commentary, ed. Christian Tams et al. (Munich, Oxford, Baden-Baden: C.H. Beck, Hart, Nomos, 2014), para 11.

${ }^{13}$ See further Ibid., para. 46.

${ }^{14}$ See also Bosnia and Herzegovina v. Serbia and Montenegro, Application of the Convention on the Prevention and Punishment of the Crime of Genocide, International Court of Justice, February 26, 2007, para. 427.

${ }^{15}$ Ibid., para. 428; Martin Mennecke, "Genocide Prevention and International Law," Genocide Studies and Prevention 4, no. 2 (2009), 171; William A. Schabas, "Genocide and the International Court of Justice: Finally, a Duty to Prevent the Crime of Crimes," Genocide Studies and Prevention 2, no. 2 (2007), 114; Christian Tams, "Article I," in Convention on the Prevention and Punishment of the Crime of Genocide: A Commentary, ed. Christian Tams et al. (Munich, Oxford, BadenBaden: C.H. Beck, Hart, Nomos, 2014), paras. 20 and 31; Stephen J. Toope, “Does International Law Impose a Duty upon the United Nations to Prevent Genocide?" McGill Law Journal 46 (2000), 187.

${ }^{16}$ United Nations, Vienna Convention on the Law of Treaties, May 23, 1969, United Nations Treaty Series, vol. 1155, 331.

${ }^{17}$ Although the VCLT is not directly (i.e. as treaty law) applicable to the UNCG, its interpretative principles reflect customary international law and are in that sense indeed applicable to the UNCG: see Tams et al., Introduction, para. 29.

${ }^{18}$ Oliver Dörr, "Article 31," in Vienna Convention on the Law of Treaties: A Commentary, ed. Oliver Dörr et al. (Heidelberg, Dordrecht, London and New York: Springer, 2014), para. 6; Mark E. Villinger, Commentary on the 1969 Vienna Convention on the Law of Treaties (Leiden and Boston: Nijhoff, 2009), Article 31, para. 37; more details provided by Jean-Marc Sorel and Valérie Boré Eveno, "Article 31 Convention of 1969," in Vienna Convention on the Law of Treaties: A Commentary, ed. Olivier Corten et al. (Oxford: Oxford University Press, 2011), para. 10.
} 
interpretation be "in good faith in accordance with the ordinary meaning to be given to the terms of the treaty in their context and in the light of its object and purpose." Accordingly, the wording of Article I UNCG (i.e. its "ordinary meaning") is the starting point of any procedure of interpretation. From then, the context of the treaty rule to be interpreted, as well as the object and purpose of the treaty in its entirety have to be assessed and then to be applied to the aforementioned wording. ${ }^{19}$ The whole procedure of interpretation is guided by "good faith," meaning that it is conducted reasonably, for example by precluding obvious abuses of rights or open conflicts with the State parties' initial objectives. ${ }^{20}$

\section{The Legal Tools of Interpretation Applied to Article I UNCG}

In light of the duty to prevent, the ordinary meaning of the wording provided by Article I UNCG is unambiguous: States "undertake to prevent" genocide. ${ }^{21}$ This means that every State party has to take reasonable measures to prevent genocide..$^{22}$ Furthermore, also the encompassing object and purpose of the UNCG is undisputed: to avert situations of genocide from unfolding (or at least continuing). However, these observations only confirm that States must act to prevent genocide. But they still do not contribute to answer the question how prevention must be done. Without prejudice to this still unsolved issue, the result that genocide must not happen is crucial and unequivocal throughout the UNCG. It is therefore right to conclude ad interim that the UNCG is strictly result-orientated towards the prevention of genocide. However, this must not be confused with a potential success (or failure) of State actions taken in compliance with the duty to prevent. As William Schabas rightly points out, States owe some conduct against genocide, but, if sufficient measures were taken, they cannot be held responsible for a failed result. ${ }^{23}$ Nevertheless, the core purpose of the UNCG is still that genocide must not happen-as a result. In other words: The object and purpose of the UNCG and the State obligations to act in compliance with its object and purpose may fall apart. On the one hand, the UNCG demands a complete result as an idealistic aim, which reflects its object and purpose. On the other hand, States might not be held accountable if the result remains incomplete, i.e. if they fail to reach this aim - as long as they seriously tried to.

The UNCG's result-orientated approach is the focal point from which a more specific content of the duty to prevent can be deduced. ${ }^{24}$ First of all, being result-orientated means that measures of prevention need to start as early as possible, which may include taking mere measures of precaution irrespective of any specific genocidal danger. For example, enacting effective domestic legislation on genocide prevention (without prejudice to more specific criminal law provisions corresponding with the duty to punish) pursuant to Article V UNCG is a suitable (and mandatory) means. ${ }^{25}$ But not only legislative powers are addressed by the Convention and the duty to prevent. Addressed is rather every State by its whole sovereign powers, including the executive branch.

${ }^{19}$ See also Tams et al., Introduction, para. 37.

${ }^{20}$ Dörr, Article 31, para. 61; Sorel and Boré Eveno, Article 31 Convention of 1969, para. 29; Villinger, Article 31, para. 6.

${ }^{21}$ Article I indeed stipulates two different obligations - literally "to prevent and to punish" - meaning "one aimed at precluding genocide from being committed, the other requiring the imposition of a penalty where genocide has been committed", Tams, Article I, para. 23. The duty to prevent "is not merged in the duty to punish, nor can it be regarded as simply a component of that duty": Bosnia and Herzegovina v. Serbia and Montenegro, Application of the Convention on the Prevention and Punishment of the Crime of Genocide, International Court of Justice, February 26, 2007, para. 427. The duty to punish is generally understood as and restricted to an "obligation to impose criminal sanctions on individuals responsible for acts of genocide or any of the other acts referred to in Article III", Tams, Article I, para. 25) and can therefore be neglected in this article.

${ }^{22}$ Bosnia and Herzegovina v. Serbia and Montenegro, Application of the Convention on the Prevention and Punishment of the Crime of Genocide, International Court of Justice, February 26, 2007, para. 162.

${ }^{23}$ Schabas, Genocide in International Law, 521 [emphasis added].

${ }^{24}$ On the duty to prevent in general: Eyal Mayroz, "The legal duty to 'prevent': after the onset of 'genocide'," Journal of Genocide Research 14, no. 1 (2012), 79; Tams, Article I, para. 43; on the relevant jurisprudence: Orna Ben-Naftali, "The Obligations to Prevent and to Punish Genocide," in The UN Genocide Convention, ed. Paola Gaeta (Oxford and New York: Oxford University Press, 2009), 37.

${ }^{25}$ However, it is uncertain how such preventive legislation should look like, see further Björn Schiffbauer, "Article V" in Convention on the Prevention and Punishment of the Crime of Genocide: A Commentary, ed. (Munich, Oxford, Baden-Baden: C.H. Beck, Hart, Nomos, 2014), para 17. 
Having recognized that, it is compelling that any (foremost executive) measure in question depends on the respective situation, particularly its gravity, proximity and specificity. ${ }^{26}$ Preventing an abstract danger certainly requires softer and more general measures such as, for example genocide-awareness training or teaching the elements of the UNCG. In contrast, a specific threat or even the presence of a genocidal situation with clear parameters as to place and time likewise requires rather forceful and tangible reactions. ${ }^{27}$ Thus, any measure dealing with how to fulfill the duty to prevent is led by the principle of proportionality. Most measures contributing to the result that genocide does not happen are suitable, but details depend on the respective situation. Again, the all-encompassing aim is the object and purpose of the UNCG, enshrined by its Article I, to avert the result of a genocide situation.

Similarly, the International Court of Justice (ICJ) pleads for preventive measures, as long as they may be effective, relative to the capacity of the State in question within the framework of international law. ${ }^{28}$ The Court also shows sympathy to the result-orientated approach of the UNCG by clarifying that its 2007 genocide judgment is not to be understood as saying "that the obligation to prevent genocide only comes into being when perpetration of genocide commences; that would be absurd, since the whole point of the obligation is to prevent, or attempt to prevent, the occurrence of the act." ${ }^{29}$ In the same paragraph the ICJ then assumes a State's "duty to act" if "a serious risk that genocide will be committed" exists. ${ }^{30}$ However, this should not be misunderstood as a restriction of the phrase cited before. Instead, the "duty to act" referred to was seen as a qualified one to actually avert an ongoing situation. Softer measures of precaution were not subject to the judgment at hand; therefore the Court was silent on them.

All this confirms the assessment made so far: States must at least try to reach the result demanded by the UNCG. There is a duty to take measures to prevent genocide. This duty exists irrespective of territory or a specific link to the State in question - each and every State party to the UNCG is addressed and charged with prevention. Behind this background, Marko Milanović concludes rightly that this "makes the obligation to prevent genocide vastly different from other due diligence obligations." ${ }^{31}$ The prevention of genocide is a global concern, whereas the details on how to act depend on the circumstances of each situation's context. Thus, taking into account the legal tools of interpretation pursuant to Article 31 para. 1 VCLT, i.e. the wording of Article I UNCG, its context to the other rules of the UNCG and in light of the encompassing object and purpose of the UNCG, the finding so far is: The content of the duty to prevent is relative to the specific situation, but it applies globally and truly literally erga omnes.

The Scope of Article I UNCG: Naming and Shaming as the Minimum Obligation to States Irrespective of content-specific issues, it has become clear that one thing is never sufficient to comply with the legal duty to prevent genocide whenever a genocidal action is at stake: doing nothing. States must always overcome the threshold of passiveness; inaction would contravene the object and purpose of the UNCG. This means that, as a minimum obligation, States must do at least something to prevent genocide. Such a something is usually initiated by words rather than stronger actions such as, for example, diplomatic negotiations or even a participation in collective (military) interventions. Words are easily spoken and do not affect the national financial budget. To utter words in terms of a genocide situation means at least to denominate the specific situation genocide;

\footnotetext{
${ }^{26}$ See also Tams, Article I, para. 46.

${ }^{27}$ This does not mean that genocide situations are generally easy to predict. Forecasts of genocide risks are generally accompanied by some degree of uncertainty, see e.g. Ernesto Verdeja, "Predicting Genocide and Mass Atrocities," Genocide Studies and Prevention 9, no. 3 (2016), 27. The level of uncertainty has to be taken into account when several means of genocide prevention are available.

${ }^{28}$ Bosnia and Herzegovina v. Serbia and Montenegro, Application of the Convention on the Prevention and Punishment of the Crime of Genocide, International Court of Justice, February 26, 2007, para. 429.

${ }^{29}$ Ibid., para. 431.

${ }^{30}$ Ibid.

${ }^{31}$ Marko Milanović, “State Responsibility for Genocide: A Follow-Up,” European Journal of International Law 18, no. 4 (2007), 685.
} 
more specifically: to name the actions referred to. Likewise, if an action is named genocide, it is, at the same time, meant to be shamed as such-at least implicitly. In terms of genocide, there is a correlation between naming and shaming. Since naming genocide points out the perpetration of the "crime of crimes"; this cannot be expressed without a shameful context. Naming and shaming a situation as genocide is the starting point for any further measures, because such determination supports clarification of whether or not the definition of genocide is met in the specific case and to sensitize other States to the situation. Global awareness is strengthened, thereby the object and purpose of the UNCG is at least not missed and the ideal result to avert a situation of genocide is (albeit only by small steps) approached. Furthermore, this minimum obligation also follows from the context with Article I UNCG in its entirety as well as with the other conventional rules on punishing genocide. Since persons having committed genocide can only be punished as perpetrators of the "crime of crimes" if they acted in a genocidal context, to denominate a situation genocide is the necessary starting point for criminal investigations in this direction. Without naming and shaming a situation as genocide, the duty to punish genocide could not be fulfilled.

Certainly, further actions are not precluded. But if actual forcible interventions against genocidal actions, for whatever reason, are neither possible nor suitable for a State, the same State can nevertheless condemn those actions as what they are: genocide. Every State has the capacity to do that. By doing so, it will not violate international law in this context. Admittedly, naming and shaming may cause a (non-violent) intervention in internal affairs of a third State; however, such intervention would be justified by Article I of the UNCG, i.e. the very duty to prevent genocide.

Moreover and essentially, naming and shaming is neither ineffective a priori but usually supports the object and purpose of the UNCG. This is generally true because labeling actions as genocide highlights the repugnance of the "crime of crimes". Widespread reception of atrocities is even stronger and provokes more profound reactions by the international community if such atrocities are not just condemned as ordinary crimes-but named and shamed as genocide. Several studies of scholars from different backgrounds have proven that naming and shaming causes significant ameliorative effects. ${ }^{32}$ Hence, naming and shaming has a deterrent effect and may potentially prevent further or similar actions from being committed. The génocidaire, who is caught in the act and shamed for his deed, may be deterred. Moreover, a specific action denounced to be genocide is unlikely to be committed again (at least under similar conditions). In addition, if a genocide situation is not labeled as such, there is from the outset no chance to take preventive measures at all.

Thus, naming and shaming is in general the least, never unreasonable and always suitable contribution to the prevention of genocide. Exceptions to this assumption might only apply if, in a certain case under its very particular circumstances, one could reasonably expect that naming and shaming would incite and encourage an assumed perpetrator to take more genocidal actions. Apart from such atypical instances, naming and shaming is the (first) necessary (though mostly not sufficient) condition to comply with both the UNCG's object and purpose and international jus cogens; since (further) measures of genocide prevention need a target: situations labeled genocide. However, as long as States in charge refrain from this minimum effort, they obviously violate compelling international law. In recent times, the German government, for example, averted such breach of international law by eventually naming and shaming the treatment of Yazidis by ISIL terrorists to be genocide as late as in August 2014. ${ }^{33}$ Meanwhile, the Yazidi situation has

\footnotetext{
${ }^{32}$ Foremost Matthew Krain, "J'accuse! Does Naming and Shaming Perpetrators Reduce the Severity of Genocides or Politiciedes?," International Studies Quarterly 65 (2012), 574; see also e.g. Justin Esarey and Jacqueline H. R. DeMeritt, Political Context and the Consequences of Naming and Shaming for Human Rights Abuse, June 26, 2016, accessed November 12, 2018, http://hdl.handle.net/1911/98873; Suzanne Katzenstein, "Reverse-Rhetorical Entrapment: Naming and Shaming as a Two-Way Street," Vanderbilt Journal of Transnational Law 46 (2013), 1079.

${ }^{33}$ A legal analysis on the Yazidi situation was provided before by Lars Berster and Björn Schiffbauer, "Völkermord im Nordirak? Die Handlungen der Terrorgruppe 'Islamischer Staat' und ihre völkerrechtlichen Implikationen," Heidelberg Journal of International Law 74, no. 3 (2014), 847; see more recently also Rosa Duarte-Herrera and Clara Ifsits, "Genocide against Yazidis: Austria's obligation to prosecute and punish returning ISIS fighters under international and national law," University of Vienna Law Review 1 (2017), 1.
} 
been widely recognized as genocide, with continued naming and shaming. ${ }^{34}$ This example shows unequivocally that naming and shaming is the first and necessary step to at least trying to avert a genocide situation from unfolding, just as the object and purpose of the UNCG demands. Even though the start of genocidal perpetration against the Yazidis could not be impeded, naming and shaming this situation was at least the first step towards stopping its continuation. That there is still a lot to do to the international community remains undisputed. But without States having started to name and shame the ISIL massacres against the Yazidis, the current situation may have been worse.

\section{The Duty to Prevent Genocide and Retroactivity}

With regard to the Yazidi situation, Germany's compliance with the UNCG does not raise any problems. Being a State party to the UNCG since 1954, there is no doubt that Germany has been under the conventional duty to contribute to the worldwide prevention of genocide as reflected in Article I UNCG. But questions arise on genocide-related situations that happened before a State was bound by the treaty law of the UNCG. As recent developments show, those situations can become practically relevant even in times of the now existing erga omnes duty to prevent genocide, and thus be subject to State actions even today. A prominent example is the genocide against the Armenians in 1915. Germany only recently (in 2016-for the first time) condemned the Ottoman massacre against the Armenians as genocide, ${ }^{35}$ although the term "genocide" did not exist at that time. Instead, "genocide" as a legal notion is firmly linked to the UNCG from 1948 (entered into force in 1951). Looking at these dates, it might be questioned whether Germany had the rightor even the duty - to name and shame the massacre against the Armenians from 1915 genocide today. It is unclear whether the wording of Article I UNCG also addresses events occurring before the erga omnes duty to prevent genocide was globally established. Can-or must-the legal term "genocide" be used to classify situations that happened before 1948 (or even before 1951)? Such questions seem to find their answers in the discussion on retroactivity in international law.

\section{The General Assumption of the UNCG's Non-Retroactivity}

Article 28 VCLT and its equivalent in general international law (customary international law and a general principle of law) ${ }^{36}$ regulate:

Unless a different intention appears from the treaty or is otherwise established, its provisions do not bind a party in relation to any act or fact which took place or any situation which ceased to exist before the date of the entry into force of the treaty with respect to that party.

Applied to the UNCG, which does not provide for a special regime dealing with situations before $1951,{ }^{37}$ international law scholars argue that the conventional duties to prevent and punish genocide are inapplicable. ${ }^{38}$ The ICJ, in its latest genocide-related judgment of 2015, also points out:

The Court considers that a treaty obligation that requires a State to prevent something from happening cannot logically apply to events that occurred prior to the date on which that State became bound by that obligation; what has already happened cannot be prevented. Logic, as well as the presumption against retroactivity of treaty obligations enshrined in Article 28 of the Vienna Convention on the Law of Treaties, thus points clearly to the conclusion that

\footnotetext{
${ }^{34}$ United Nations Human Rights Council, “They came to destroy:" ISIS Crimes Against the Yazidis, June 15, 2016 (UN Doc. A/ HRC/32/CRP.2)

${ }^{35}$ German Bundestag, Resolution concerning the situation in Armenia in 1915, June 2, 2016 (official record no. 18/8613).

${ }^{36}$ Frédéric Dopagne, "Article 28 Convention of 1969," in Vienna Convention on the Law of Treaties: A Commentary, ed. Olivier Corten, et al. (Oxford: Oxford University Press, 2011), para. 5; Kerstin Odendahl, "Article 28," in Vienna Convention on the Law of Treaties: A Commentary, ed. Oliver Dörr et al. (Heidelberg: Springer, 2014), para. 5; Villinger, Article 28, para. 13.

${ }^{37}$ Tams et al., Introduction, para. 44.

${ }^{38}$ See e.g. Ben Saul, "The Implementation of the Genocide Convention at the National Level," in The UN Genocide Convention, ed. Paola Gaeta. (Oxford and New York: Oxford University Press, 2009), 72.
} 
the obligation to prevent genocide can be applicable only to acts that might occur after the Convention has entered into force for the State in question. [...] A State which is not yet party to the Convention when acts of genocide take place might well be in breach of its obligation under customary international law to prevent those acts from occurring but the fact that it subsequently becomes party to the Convention does not place it under an additional treaty obligation to have prevented those acts from taking place. ${ }^{39}$

The-quite obvious-conclusion from this would be: The UNCG, in its material parts, turns a blind eye on events prior to its entering into force. This is definitively true to the duty to punish genocide, for a treaty imposing criminal penalties with retroactive effects would be extremely problematic by international human rights standards. But what does the UNCG's nonretroactivity mean to the much broader duty to prevent genocide? Do international lawyers really tell and believe that, for example, the Holocaust is irrelevant to the UNCG and therefore cannot be classified genocide? A widespread blanked presumption of non-retroactivity would indeed lead to this conclusion. Such an odd and even absurd result truly demands for a more precise assessment of the ICJ's arguments as well as the wording of Article 28 VCLT.

\section{Retroactivity and the Duty to Prevent Genocide}

Article 28 VCLT stands under the precondition " $[\mathrm{u}]$ nless a different intention appears from the treaty." The object and purpose of the UNCG is (inter alia, as shown above) to prevent future (and stop ongoing) genocide situations. Thus, the duty to prevent genocide is logically directed towards the present and the future. The problem of retroactivity, instead, arises whenever a State has allegedly not complied with this duty and therefore might be held accountable and subjected to international responsibility. In this respect, States usually cannot be treated different from individuals: both have to pay dues only for violations of obligations having existed at the time of their respective deeds or omissions. Otherwise, accountability would fail. This is exactly the meaning of the rule reflected in Article 28 VCLT, namely that a treaty's "provisions do not bind a party in relation to any act or fact which took place or any situation which ceased to exist before the date of the entry into force." Or, more pointed in the words of the ICJ cited above: "what has already happened cannot be prevented."

But does this also mean that events from before 1951, although matching the (undisputed core of the) definition of genocide under international law, are irrelevant? The ICJ seems to answer in the affirmative by opining:

Logic [...] points clearly to the conclusion that the obligation to prevent genocide can be applicable only to acts that might occur after the Convention has entered into force for the State in question. ${ }^{40}$

Taking these words literally, the Court apparently believes that measures to comply with the duty to prevent must be directed pointedly against a specific (ongoing or future) action without looking back. If this was true, the Court's opinion would reflect only a one-way understanding of logic-for at least two reasons: First, the ICJ then would ignore the (already cited) caveat to the object and purpose of the UNCG enshrined in Article 28 VCLT. But, again, the object and purpose is to prevent genocide in general by a result-orientated approach. It is hard to believe that the Court intended to deny that. ${ }^{41}$ Second, the result-orientated approach by the UNCG to prevent genocide is-indeed by logic-not limited to specific, well determined genocidal acts. Instead, as seen above, it applies generally to an undetermined (and hopefully minimal) amount of possible genocide situations. Thus, the duty to take measures of prevention does not start as late

\footnotetext{
${ }^{39}$ Croatia v. Serbia, Application of the Convention on the Prevention and Punishment of the Crime of Genocide, International Court of Justice, February 3, 2015, para. 95.

${ }^{41}$ The fact that the ICJ qualifies the duty to prevent as a "duty to act" (supra notes 29 and 30) refers to the obligation of each individual State not to be inactive, not to the general object and purpose of the Convention.
} 
as when perpetrators grab their slaughter knives and atrocities appear to be imminent. Measures of prevention are rather to be taken as early as when the first spark of a genocidal thought might come to a potential perpetrator's mind. Otherwise genocide prevention would hardly be effective but rather degenerate into a hollow phrase. That would clearly contravene the object and purpose of the UNCG and particularly its Article I. Therefore, the duty to prevent genocide cannot be completely linked to the general non-retroactivity of the UNCG.

\section{Retroactivity in Focus: Distinctions between Past and Future Situations}

The answer to these facts in terms of international law is distinction in detail. There is a difference also in international law between State responsibility on the one hand and general compliance with the duty to prevent genocide on the other hand. Retroactivity of the UNCG is only (and rightly) precluded when it comes to State responsibility under international law. That was indeed the only aspect the ICJ had to rule on in its two genocide cases. Thus, it should not be presumed that the ICJ would be reluctant to distinguish if it needed to. But State responsibility is only one side of the coin which the duty to prevent genocide is engraved in. The other side is every State's obligation to contribute to the result demanded by the UNCG that genocide in general does not happen, irrespective of States can be held accountable for any insufficient performance. Neither the UNCG, nor general international law outlaws assessing situations from the pre-Conventional era under the legal regime of the UNCG. Only State responsibility for those situations cannot be based on the UNCG.

In contrast, whenever the object and purpose of the UNCG so demands, States may not and must not ignore events from the time before the UNCG entered into force. Being aware of this distinction, the duty to prevent genocide requires States to answer indeed two questions: first, whether to act; second, how to act. The starting point to take measures against genocide is the entering into force of the UNCG with respect to the concerned State - and the first question is to be answered: whether. Before being bound by the UNCG, States may (without prejudice to jus cogens obligations) discretionarily decide whether they take measures. From the day of the UNCG's binding effect with respect to the State in question, such discretion converts into the duty to prevent ongoing and future genocide situations. From then, actions to prevent genocide have to be taken mandatorily - at least as a soft measure of precaution contributing to the all-encompassing object and purpose of the result-orientated approach. Then the second question becomes crucial: what measures are to be taken, i.e.: how to act. This important differentiation is crucial to rightly comply with all obligations of the UNCG. The reference point with respect to measures of genocide prevention can also reach back to the past-if and whenever future situations can be averted that way. In this respect, retroactivity of the UNCG is to be accepted, if the issue of retroactivity is addressed that way at all. Since the duty to prevent genocide remains to be directed to the present and the future, this does not cause retroactive effects at all. But the references taken to avert genocide in future indeed may still reach back to the past.

\section{The Duty to Prevent Genocide between the Past and the Future}

As shown above, the UNCG is not a technocratic treaty but a living instrument that subordinates everything to its encompassing, result-oriented object and purpose: the prevention of genocide. The prevention of genocide necessarily links events and aspects from the past with those in the future. Genocide (not only, but also) as a legal term has developed from the experience of past events and exists to define what exactly to prevent in the future.

Learning from the Past to be Aware in the Future

In other words: Prevention also means to recognize what went wrong in the past to be aware that the same or similar developments must be thwarted in the future. This leads back to the minimum requirement to comply with the duty to prevent genocide: naming and shaming. Shaming genocidal events from the pre-UNCG era and naming them "genocide" strongly supports the disclosure of elements of the "crime of crimes" and sharpens the global awareness towards akin future events. Just recently, in a broader context, Kerry E. Whigham has elaborately explained that remembering 
the past is a suitable and important element of prevention in the future..$^{42}$ This is equally true to international law and specifically to the legal duty to prevent genocide. Moreover, as mentioned above, naming and shaming has positive effects. ${ }^{43}$ Even after 70 years of a codification against genocide the ideal of a genocide-free world is far from being reached. This means also that learning from the past is far from being exhausted, it is rather a continuing course of development. Or, as James Waller recently argued: "the world as it is now is not the world as it has to be." ${ }^{44}$ Genocide in international law might be even more topical than before, making the process of reappraising the past even more urgent in order to prevent future atrocities. In terms of genocide, this means that past atrocities which meet the present definition of genocide as reflected by Article II UNCG need to be labeled as such to identify and globally communicate what to prevent in the future.

This understanding of genocide prevention by naming and shaming indeed conducted the whole drafting process of the UNCG, which started shortly after the Second World War and was molded by the unutterable impressions from the Holocaust. The experiences of those days ignited the need to find a name for what had just happened in order to choke comparable future situations in their very beginning. ${ }^{45}$ Thus, naming and shaming reflects the spirit of the UNCG and the eventually emerged erga omnes duty to prevent genocide.

From a Right to Name and Shame...

These remarks inevitably lead to the conclusion that every State has a right to name and shame situations as genocide even if these situations took place before the UNCG was in force. If the need to prevent genocide is taken seriously, international law cannot not preclude a State from naming and shaming situations that undoubtedly fall under the definition provided by the UNCG, since any other result would run contrary to the UNCG's object and purpose and would contravene jus cogens.

\section{...Towards a Duty to Name and Shame}

However, does the right to name and shame past situations as genocide correspond with a duty under international law to do so? The UNCG's major purpose to prevent genocide as effectively as possible would opt for the affirmative. But it needs to be kept in mind that the facts of any situation in question must be clear and thoroughly assessed because a State needs to be absolutely certain about the elements of genocide. For this reason, with respect to past situations, a graded (instead of an absolute) duty to name and shame appears to be more adequate. Aspects of such graduation - emanating from the principle of proportionality in international law-could be the following: The closer a State was involved in the respective situation (for example geographically, by bilateral relations or as a host for refugees), the better it knows the facts and thus can assess whether or not genocide was present. This proximity to a situation is crucial also to maintain the credibility of the duty to prevent genocide. Mere speculations whether a situation could be labeled genocide would even contravene the aim of a genocide-free world because the concept of genocide as a whole then would lose clarity. Thus, a duty to name and shame in the light of the object and purpose of the UNCG depends on a qualified link between the situation referred to and the State to name and shame.

The Holocaust, for example, concerned virtually every State in the world and obviously matches the definition of genocide. A more qualified link to the whole world could hardly exist. It is therefore the duty of every single State to name and shame the Holocaust as genocide. In contrast, the situation concerning the Armenian population in the Ottoman Empire during the First World War in 1915 did not immediately gain global attention in those times. Although this event

\footnotetext{
${ }^{42}$ Kerry E. Whigham, "Remembering to Prevent: The Preventive Capacity of Public Memory," Genocide Studies and Prevention 11, no. 2 (2017), 57.

${ }^{43}$ Supra note 32.

${ }^{44}$ James Waller, Confronting Evil: Engaging Our Responsibility to Prevent Genocide (Oxford: Oxford University Press, 2016), xxvii.

${ }^{45}$ See e.g. Yuval Shany, "The Road to the Genocide Convention and Beyond," in The UN Genocide Convention, ed. Paola Gaeta. (Oxford and New York: Oxford University Press, 2009), 5; Tams et al., Introduction, para. 8.
} 
made an obvious example of genocide under the conventional definition, it cannot be expected that every State was or is close enough to the facts of this massacre. Thus, a remote and completely uninvolved State like, for example, Panama (a signatory State from the first hour of the UNCG) cannot be expected to condemn a situation from the other edge of the world (though it still may do so). Turkey, however, a State party to the UNCG since 1950, definitely is in charge. But Turkey instead conceals the atrocities committed by its predecessor's troops and even prosecutes any person naming them genocide. This is nothing else but a grave and flagrant violation of the UNCG.

On the other hand, the Armenian situation is indeed a good (although indeed terribly sad) example of how a duty to name and shame can be complied with: As mentioned above, Germany only recently named and shamed the Ottoman massacre against the Armenians as genocide. ${ }^{46}$ This was almost 62 years overdue (since Germany's ratification of the UNCG in 1954), not to mention that many other States had already recognized the Armenian genocide. ${ }^{47}$ Moreover, the German Reich as the predecessor of the Federal Republic of Germany was not only an ally to the Ottoman Empire but also knew about the atrocities committed and nevertheless omitted to take any effective measure against them. Thus, Germany was sufficiently close to the actions, which were even well documented by its own diplomatic staff, and was therefore able to assess the situation properly. After all, a qualified link cannot be denied. Nevertheless, Germany long refrained from naming and shaming the Armenian genocide-for political reasons. Such motives cannot justify noncompliance with the duty to prevent genocide. However, after the Bundestag resolution - and a formal expression of protest by Turkey - the German government (by its press release of September $2,2016)$ strengthened its parliament and proved to be willing to condemn genocide seriously. ${ }^{48}$

The government's legal opinion was certainly not completely precise when chancellor Angela Merkel pointed out "that Bundestag resolutions are political in nature and are not legally binding." This is only right with respect to questions of State responsibility, which cannot be triggered retroactively. As seen above, the question of being held accountable for past genocides has to be split from the question whether such situations fall under the contemporary definition of genocide. Underlining that there is no connection between claims for compensation under international law ${ }^{49}$ on the one hand and recognizing genocide on the other hand may even encourage more States to name and shame past situations as genocide. Perhaps this late perception made it finally easier for Germany not to do more than finally fulfill its obligation to name and shame the Armenian situation as genocide. This duty evolved from the conventional duty to prevent genocide.

\section{Conclusion and Outlook}

Almost 70 years after the UNCG entered into force, the prevention of genocide is not yet a glorious chapter in the modern era of international law. After Srebrenica and Rwanda, which awakened the world to genocide and brought the issue back on the international agenda, annihilations of groups still take their course. Darfur was largely ignored in 2007; likewise the ongoing genocide against the Yazidis. But is this really surprising? How can members of the international community ${ }^{50}$ be legitimized to take effective measures to avert remote attacks against mankind if they fail to process their past? Naming and shaming past situations of genocide might be painful; it may mean conceding one's own (respectively one's ancestors') guilt. But in the absence of condemnation, perpetrators in other parts of the world certainly feel encouraged to carry out atrocities. The UNCG has recognized that, and demands all States take any possible measure to prevent genocide-

\footnotetext{
${ }^{46}$ Supra note 35 .

${ }^{47}$ See the overview on http://www.genocide-museum.am/eng/states.php.

${ }^{48}$ Federal Republic of Germany, "Government does not distance itself from the Armenia resolution," Press Release, September 2, 2016.

${ }^{49}$ Victims of genocides from the pre-UNCG era are generally not entitled to compensation for genocide under international law: Patrick O. Heinemann, "Die deutschen Genozide an den Herero und Nama: Grenzen der rechtlichen Aufarbeitung," Der Staat 55, no. 4 (2016), 473.

${ }^{50}$ Without prejudice to the specific concept behind the notion of "international community", see further William E. Conklin, "The Peremptory Norms of the International Community," European Journal of International Law 23, no. 3 (2012), 847 .
} 
including to avow past misconduct preventing genocide is indeed not just a but the obligation, regardless of the focus: Germany and the Herero and Nama, ${ }^{51}$ the United States and Native Americans, Australia and Aborigines - there are many more examples around the world. A lot of work remains to be done, and the object and purpose of Article I UNCG sets that work's guideline in an international law context: To prevent future genocide situations can only succeed if the past is not concealed.

\section{Acknowledgements}

This article is based on a contribution to the thirteenth meeting of the International Association of Genocide Scholars at the University of Queensland in Brisbane from July 9 to 13, 2017.

\section{Bibliography}

Ben-Naftali, Orna. "The Obligations to Prevent and to Punish Genocide." In The UN Genocide Convention, edited by Paola Gaeta, 27-57. Oxford and New York: Oxford University Press, 2009.

Berster, Lars and Björn Schiffbauer. "Völkermord im Nordirak? Die Handlungen der Terrorgruppe 'Islamischer Staat' und ihre völkerrechtlichen Implikationen." Heidelberg Journal of International Law 74, no. 3 (2014), 847-872.

Conklin, William E. "The Peremptory Norms of the International Community." European Journal of International Law 23, no. 3 (2012), 837-861. https://doi.org/10.1093/ejil/chs048

Corten, Olivier and Pierre Klein. Vienna Convention on the Law of Treaties: A Commentary. Oxford: Oxford University Press, 2011. https://doi.org/10.1093/acprof:oso/9780199588916.003.0001

Dörr, Oliver and Kirsten Schmalenbach. Vienna Convention on the Law of Treaties: A Commentary. Heidelberg, Dordrecht, London and New York: Springer, 2012. https://doi.org/10.1007/978$\underline{3-642-19291-3}$

Duarte-Herrera, Rosa and Clara Ifsits. "Genocide against Yazidis: Austria's obligation to prosecute and punish returning ISIS fighters under international and national law." University of Vienna Law Review 1 (2017), 1-33.

Esarey, Justin and Jacqueline H. R. DeMeritt. Political Context and the Consequences of Naming and Shaming for Human Rights Abuse. June 26, 2016. Accessed November 12, 2018. http://hdl. handle.net/1911/98873.

Federal Republic of Germany. German Government. "Government does not distance itself from the Armenia resolution." Press Release, September 2, 2016. Accessed November 12, 2018. https://www.bundesregierung.de/Content/EN/Artikel/2016/09 en/2016-09-02-seibertarmenien.html.

German Bundestag. Resolution concerning the situation in Armenia in 1915. June 2, 2016. Official record no. 18/8613. Accessed November 12, 2018. https://www.bundestag.de/dokumente/ textarchiv/2016/kw22-de-armenier/423826.

Heinemann, Patrick O. "Die deutschen Genozide an den Herero und Nama: Grenzen der rechtlichen Aufarbeitung." Der Staat 55, no. 4 (2016), 461-487.

Katzenstein, Suzanne. "Reverse-Rhetorical Entrapment: Naming and Shaming as a Two-Way Street." Vanderbilt Journal of Transnational Law 46 (2013), 1079-1099.

Krain, Matthew. "J'accuse! Does Naming and Shaming Perpetrators Reduce the Severity of Genocides or Politiciedes?" International Studies Quarterly 65 (2012), 574-589. https://doi. org/10.1111/j.1468-2478.2012.00732.x

Lemkin, Raphael. "Genocide as a Crime under International Law." United Nations Bulletin vol. IV, January 15, 1948.

Mayroz, Eyal. "The Legal Duty to 'Prevent': After the Onset of 'Genocide'." Journal of Genocide Research 14, no. 1 (2012), 79-98. https://doi.org/10.1080/14623528.2012.649897

Mennecke, Martin. "Genocide Prevention and International Law." Genocide Studies and Prevention 4, no. 2 (2009), 167-175. https://doi.org/10.3138/gsp.4.2.167

${ }^{51}$ See for details Heinemann, Die deutschen Genozide, 461. 
Milanović, Marko. "State Responsibility for Genocide: A Follow-Up." European Journal of International Law 18, no. 4 (2007), 669-694. https://doi.org/10.1093/ejil/chm043

Saul, Ben. "The Implementation of the Genocide Convention at the National Level." In The UN Genocide Convention, edited by Paola Gaeta, 58-83. Oxford and New York: Oxford University Press, 2009. https://doi.org/10.1093/law/9780199570218.001.0001

Schabas, William A. "Genocide and the International Court of Justice: Finally, a Duty to Prevent the Crime of Crimes." Genocide Studies and Prevention 2, no. 2 (2007), 101-122. https://doi. org/10.3138/gsp.2.2.101

-------. Genocide in International Law, 2nd ed. Cambridge: Cambridge University Press, 2010.

Shany, Yuval. "The Road to the Genocide Convention and Beyond." In The UN Genocide Convention, edited by Paola Gaeta, 3-26. Oxford and New York: Oxford University Press, 2009.

Tams, Christian, Lars Berster, and Björn Schiffbauer. Convention on the Prevention and Punishment of the Crime of Genocide: A Commentary. Munich, Oxford, and Baden-Baden: C.H. Beck, Hart, Nomos, 2014. https://doi.org/10.5771/9783845258911

Tladi, Dire. Second report on jus cogens. United Nations General Assembly, Sixty-ninth session. March 16, 2017. UN Doc. A/CN.4/707.

Toope, Stephen J. "Does International Law Impose a Duty upon the United Nations to Prevent Genocide?" McGill Law Journal 46 (2000), 187-194.

United Nations. General Assembly Resolution 260, Convention on the Prevention and Punishment of the Crime of Genocide. December 9, 1948. UN Doc. A/RES/260(III).

-------. Vienna Convention on the Law of Treaties. May 23, 1969. United Nations Treaty Series, vol. $1155,331$.

United Nations General Assembly. Rome Statute of the International Criminal Court. July 17, 1998. United Nations Treaty Series, vol. 2187, 3.

United Nations Human Rights Council. "They came to destroy:" ISIS Crimes Against the Yazidis. June 15, 2016. UN Doc. A/HRC/32/CRP.2.

Verdeja, Ernesto. "Predicting Genocide and Mass Atrocities." Genocide Studies and Prevention 9, no. 3 (2016), 13-32. https://doi.org/10.5038/1911-9933.9.3.1314

Villinger, Mark E. Commentary on the 1969 Vienna Convention on the Law of Treaties. Leiden and Boston: Nijhoff, 2009.

Waller, James. Confronting Evil: Engaging Our Responsibility to Prevent Genocide. Oxford: Oxford University Press, 2016.

Whigham, Kerry E. “Remembering to Prevent: The Preventive Capacity of Public Memory." Genocide Studies and Prevention 11, no. 2 (2017), 53-71. https://doi.org/10.5038/1911-9933.11.2.1447 